The coming of the railways to Europe 
10.5920/railways.5 
The first RaIlWays were constructed in Great Britain carrying passengers and providing the much needed transportation of natural resources, such as coal and iron, to fuel the Industrial Revolution. After the early success of the Liverpool and Manchester line in 1830, several European countries followed suit with the development of the railways hastening the pace of industrialization across Europe. For both freight and passengers, the railways proved to be a better and cheaper alternative than waterways and roads, many of which were impassable during the winter. The railways had an effect on many aspects of society: they stimulated economic development; they were a significant tool in nation building; and for some countries they were an important instrument of military strategy. The impact of the railways was huge in terms of progress and development. The railways created new towns, new industries and new concepts; railways became a symbol of modernity. The historian Eric Hobsbawm wrote

By 1850, the railways had reached a standard of performance not seriously improved upon until the abandonment of steam in the mid-twentieth century, their organization and methods were on a scale unparalleled in any other industry, their use of novel and science-based technology (such as the electric telegraph) unprecedented. They appeared to be several generations ahead of the rest of the economy, and indeed 'railway' became a sort of synonym for ultramodernity in the 1840s, as 'atomic' was to be after the Second World War. ${ }^{1}$

Thousands of kilometres of lines had transformed time, space and distance. The speed of even the earliest locomotives outstripped any means of transport that had come before, so given the enormity of the impact and the far-reaching effects, it comes as no surprise that the railways appealed to the artistic imagination of nineteenth-century composers. Jeffrey Richards and John MacKenzie when writing of the impact of the railways on popular culture put this appeal as 'responding to the immediacy of the sensations they provoke, to the bold iconographic power, strength and modernity of the steam 
engine, to the kaleidoscopic nature of train travel, to the whirl and bustle and breathlessness of transience. ${ }^{2}$

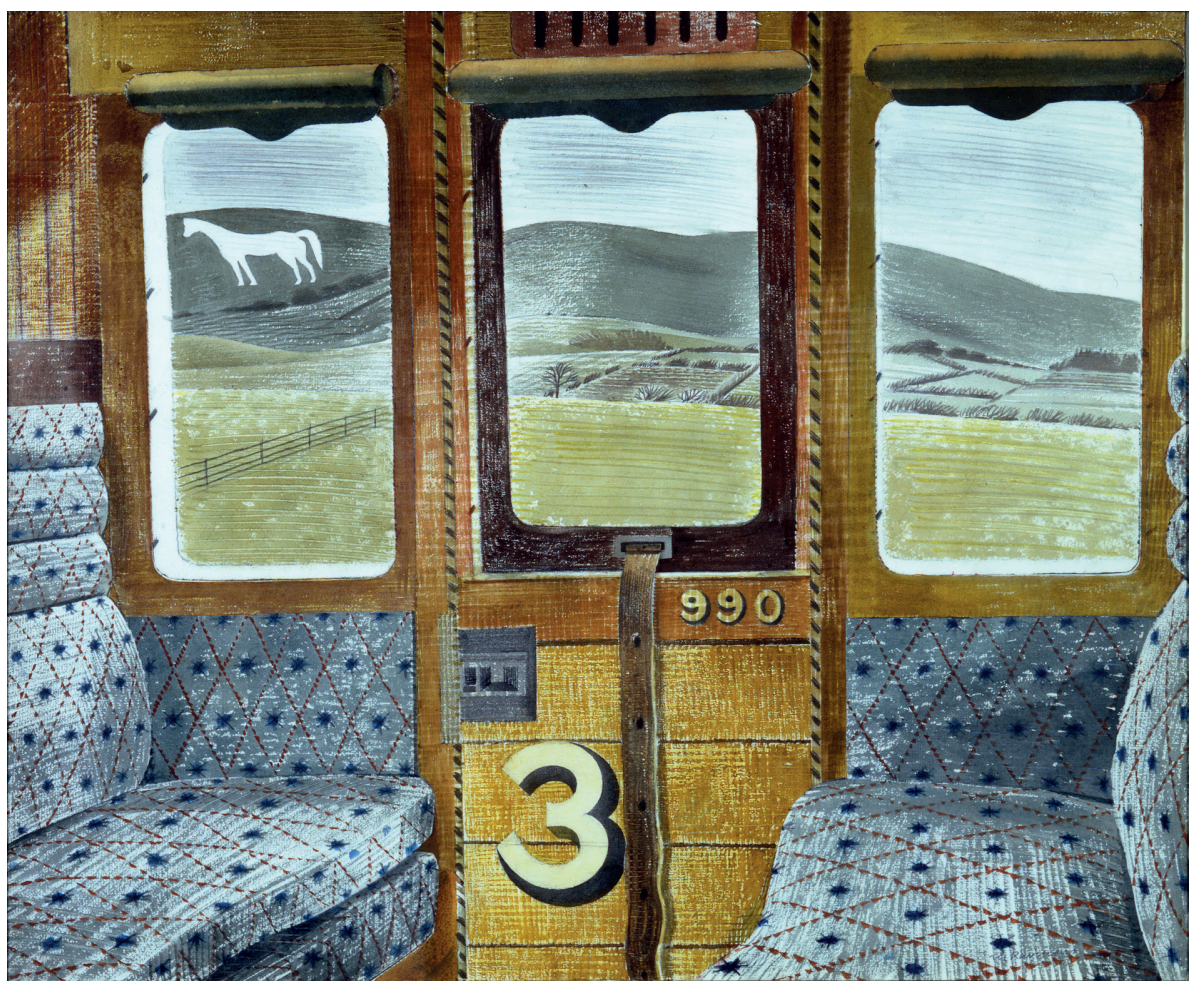

Train Landscape, Ravilious, Eric, 1903-1942

Photo credit. Aberdeen Art Gallery \& Museums 


\section{The coming of the railways to Austria, 5 the Strauss family and railway music}

The first public railway in Austria was also the first in continental Europe, a horse-drawn line with an unusual gauge; it opened in 1832 and ran from Budweis $^{3}$ to Linz, eventually developing into a network of lines stretching for more than 270 kilometres in the valleys of Upper Austria. However, the first line in Austria to become part of the modern network was a steam hauled, standard gauge line, opened in 1837 between Floridsdorf (near Vienna) and Deutsch Wagram. This was the first section of the Kaiser FerdinandsNordbahn which eventually ran between Vienna and Warsaw. Austria's primary railway network developed rapidly in the mid-nineteenth century, partly in a bid to knit the Austro-Hungarian Empire together. By 1845 more than 650,000 passengers each year travelled along the Nordbahn line. ${ }^{4}$ The Nordbahn followed a relatively simple route travelling largely across lowlands. In contrast the Südbahn, reaching south across the Alps to the Adriatic via the Semmering Pass, was built across difficult mountainous terrain which was more challenging in its construction with many tunnels and impressive multiple-arch viaducts. The Brenner Pass offered further difficult terrain, crossing avalanche runs with steep climbs, tight curves and long tunnels. In 1856 construction began westwards from Vienna with the Kaiserin Elisabeth Bahn, the first section of what was to become the Westbahn running from Vienna to Salzburg. It opened for traffic in 1860. Around this time railway construction more or less came to a standstill because of the war against Prussia but in 1866 it was pushed forward to revive the economy and the following years were marked by a railway construction boom. ${ }^{5}$

Railway building continued across Europe in phases. The last European country to build a railway was Greece; its first line, the Piraeus-Athens service, 
opened in 1869. By the early 1900s there was a grid of lines across Europe and several cross-border connections had been made creating a new and exciting network of technology.

There are many nineteenth-century pieces celebrating the coming of the railways; some were commissioned for the opening of lines; many evoke the scene using the instruments of the orchestra to imitate train sounds; and others focus on the danger and exhilaration associated with exciting new means of travel. For fifty years the Strauss family were at the forefront of the fashion for railway music.

\section{The Strauss family}

Johann Strauss I spent much of the early years of his musical career playing in pubs and he played a big part in establishing the waltz as a musical form, taking it to new heights of popularity. Robert Barry writes of Johann Strauss I that 'his career began playing the violin in the back room of a pub' and that he 'transmuted all the crowd-pleasing turns necessary for a bar-room entertainer into the new dance form of the Viennese waltz.' Johann Strauss I (or the Elder as he is sometimes known) was born in 1804, the son of an innkeeper and was brought up in a Viennese tavern. He 'grew up amid the sounds of the wandering "Beer fiddlers" and the various folk dances they brought with them from their travels along the Danube. ${ }^{7}$ As a teenager he joined Joseph Lanner's string ensemble playing and writing dance pieces for the small group which eventually expanded to split into two popular string orchestras; Lanner conducted one and Strauss the other. In 1825 Strauss began giving concerts at Zum roten Hahn (The Red Rooster) where he met his wife to be Maria Anna. The couple married in July 1825 and their son, the future 'Waltz King', Johann II was born in October that year. They went on to have five more children; two of these Josef (1827-70) and Eduard (1835-1916) also went on to have successful careers as composers and conductors.

Strauss was energetic, prolific and very hard working. In 1829 his career was boosted when he signed a six-year contract with the owner of the fashionable Zum Sperlbauer, often known as the Sperl, the biggest dance hall in Vienna. In his early career Strauss appeared at dance establishments throughout Vienna, but realized that in order to secure an international reputation he needed to go further afield and soon began tours across Europe including two highly successful visits to Great Britain. In October 1838, Strauss set off on the 
lengthiest and most ambitious of his tours, first through southern Germany, on to Strasbourg and then Paris where the 26-strong orchestra stayed for four months. There his concerts received an outstanding reception and were attended by many prominent musicians including Cherubini, Paganini and Berlioz. The French composer Hector Berlioz wrote

We knew the name of Strauss, thanks to the music publishers...that was all; of the technical perfection, of the fire, the intelligence and the rhythmic feeling which his orchestra displays, we had no notion. ${ }^{8}$

Journal des Débats (10 November, 1837)

Most of the touring would be by means of uncomfortable horse drawn carriages, but as the orchestra left Paris and continued through Belgium and the Netherlands they were able to take advantage of the new and extensive railway system. Largely as a result of Strauss's tours, the waltz gained huge popularity abroad, both in the ballroom and at promenade concerts such as those held at the Vauxhall Pavilion at Pavlosk near St Petersburg, and the Tivoli Gardens in Copenhagen. Periods of tours and residences in Vienna followed. In 1849, shortly after the second British visit with 46 concerts in eight weeks, Strauss returned to Vienna exhausted. He fell ill and a few weeks later he died from scarlet fever.

After his father's death, Johann Strauss II took over what had become the family business leading it to new heights of international fame. By the 1850s the Strauss business had 200 employees including coach drivers, music copyists and bookkeepers. In 1853 he broke down from exhaustion and handed over control to his brothers. To help his recovery he went to the spa town of Bad Gastein. Whilst he was there he was to take up another lucrative business opportunity when the Russian director of the Tsarskoe Selo Railway invited him to take up a summer residency at the station and entertainment venue in Pavlovsk near St Petersburg. The younger Strauss toured widely across Europe using the railway network that connected the German speaking spa towns. The spa resorts were an important market for the orchestra with their luxury hotels, casinos, theatres, restaurants and other popular entertainment venues for light music. ${ }^{\text {? }}$

The Strauss name was now synonymous with the waltz, even more so with the later appearance on the scene of Johann's two brothers, Josef in 1853 and 
Eduard in 1859. Each of the three brothers had a stint of conducting the Strauss Orchestra. Although Josef had embarked on a successful career as an engineer and designer, he joined the orchestra in the 1850s and took over as conductor. In June 1870, Josef collapsed whilst conducting and fell unconscious. Seven weeks later he died at the young age of 42 . After his untimely death, the youngest brother Eduard took over responsibility for the Strauss Orchestra.

In the 1890s Eduard Strauss undertook a highly successful tour of North America, along with concert tours through Europe and residencies in Vienna. In 1897 he discovered to his horror that his two sons, with his wife's knowledge, had squandered much of his earnings. Undeterred he set about recouping his fortune with another tour of North America. Whilst there he was injured in a train accident in Pittsburgh station; his collarbone was dislocated and he was forced to conduct with his left hand. The concert tour ended in New York in 1901 at which point he decided that after 39 years with the orchestra he had had enough. He disbanded the orchestra the following morning and retired from public life. ${ }^{10}$ Six years later he took the Strauss Orchestra archives to a furnace in Vienna and burnt the lot. In 1916 he died of a heart attack and, as the Strauss expert, Peter Kemp wrote A golden epoch of Viennese musical history had been brought to a close. ${ }^{11}$

Between them the Strauss family played a large part in creating the growing demand for light and accessible entertainment music, consequently introducing the popular-music industry to Europe. ${ }^{12}$ In the words of Robert Barry, their music was unabashedly commercial; catering to an urban, middlebrow, leisuretime audience; and serving no religious or secular ritual function; Strauss's music represented a whole new way of looking at music.'. ${ }^{13}$ 


\section{The music of the Strauss family}

\section{0 railway pieces by members of the Strauss family}

\begin{tabular}{|l|l|l|}
\hline TITLE & COMPOSER & DATE \\
\hline $\begin{array}{l}\text { Eisenbahn-Lust-Walzer (Railway Pleasure } \\
\text { Waltzes) Op. 89 }\end{array}$ & Johann Strauss I 1804-49 & 1836 \\
\hline Spiralen (Spirals) Op. 209 & Johann Strauss II 1825-99 & 1858 \\
\hline Accellerationen (Accelerations) Op. 234 & Johann Strauss II & 1860 \\
\hline Gruss an München (Greetings to Munich) Op.90 & Josef Strauss 1827-70 & 1860 \\
\hline Vergnügungszug (Pleasure Train Polka) Op. 281 & Johann Strauss II & 1864 \\
\hline Babn Frei! (Line Clear) Op. 45 & Eduard Strauss 1835-1916 & 1869 \\
\hline Mit Dampf(With Steam) & Eduard Strauss & 1871 \\
\hline Tour und Retour (Round Trip) & Eduard Strauss & 1875 \\
\hline Lustfahrten (Pleasure Journeys) Op. 177 & Eduard Strauss & 1879 \\
\hline Feuerfunken (Sparks of Fire) Op. 185 & Eduard Strauss & 1880 \\
\hline
\end{tabular}

\section{The waltzes}

Waltz music is in triple time (three beats in a bar), quite fast, often with catchy tune and a simple oom-cha-cha chordal accompaniment. The dance with its fast-moving, twirling and embracing couples, at first shocked polite society because it required bodily contact between the dancers unlike the group dances and stately minuets which had come before. But it was this intimate sensuality which added to its popularity. The sensuous nature of dancing the waltz is vividly portrayed by Gustave Flaubert in this famously erotic description of a waltz in his novel Madame Bovary

They began slowly, then went more rapidly. They turned; all around them was turning - the lamps, the furniture, the wainscoting, the floor, like a disc on a pivot. On passing near the doors the bottom of Emma's dress caught against his trousers.

Their legs commingled; he looked down at her; she raised her eyes to his. A torpor seized her; she stopped. They started again, and with a more rapid movement; the Viscount, dragging her along disappeared with her to the end 
of the gallery, where panting, she almost fell, and for a moment rested her head upon his breast. And then, still turning, but more slowly, he guided her back to her seat. She leaned back against a wall and covered her eyes with her hands. ${ }^{14}$

Gustave Flaubert: Madame Bovary

The second half of the nineteenth century was a time when the waltz craze was at its height. In 1833 the German journalist and critic Heinrich Laube wrote of an evening of dancing to Strauss's music at the Sperl, the venue which the Strauss Orchestra packed on a regular basis.

To hold the unrestrained crowds in check a long rope is taken, and all who remain in the middle are separated from those actually occupied in dancing. But the boundary is flexible and yielding, and only in the steadily whirling girls' heads can one distinguish the stream of dancers. The couples waltz intoxicated through all the accidental or intentional obstructions and wild delight is let loose..+ 15

\section{Eisenbabn-Lust-Walzer (Railway Pleasure Waltzes)}

The Eisenbabn-Lust-Walzer (Railway Pleasure Waltzes) were composed in 1836 in advance of the much anticipated 1837 opening of the line between Floridsdorf and Deutsch Wagram, the first section of the Kaiser FerdinandsNordbahn. The first performance took place on July 18, 1836 at the newly built dance hall which was part of Zur golden Birn (The Golden Pear), a very popular hotel and restaurant in the suburbs of Vienna. ${ }^{16}$ The work was part of the venue's summer gala, an 'Assemblée mit Ball' (Assembly with Ball) under the title 'Buntes aus der Zeit' (Topical miscellany), performed at midnight against a 30-metre backdrop depicting a railway journey. The music was so rapturously received that it had to be repeated several times.

In the 1830s most waltzes, like the Eisenbahn-Lust-Walzer, were in sets of five plus the Introduction and a Coda (end section). The train journey gets off to a start in the Introduction with loud repeated brassy chords and tremolo strings leading up to dissonant off-beat accented chords. The whole arresting passage is repeated and then the excitement builds up more. After a silent bar the music suddenly becomes quieter, only to build up again with a climbing chromatic scale moving towards the final loud chords of the Introduction. 
The five waltzes bear all the typical characteristics of the form: they are in triple time; quite fast; melodious; and with a simple chordal accompaniment. Most of the time the music uses an oom-cha-cha accompaniment where the bass note is played on the first beat of the bar and the remaining notes of the chord are played on beats two and three - oom-cha-cha, oom-cha-cha - a rhythm which lends itself to the sound of a train chugging along. Julian Johnson refers to this style of melody and accompaniment as a kind of 'prototechno music which...operates with the thrum of the machine underlying a slow-moving melodic line. ${ }^{17}$ In Waltz No. 1, the train is on its way, chugging along in the way he describes:
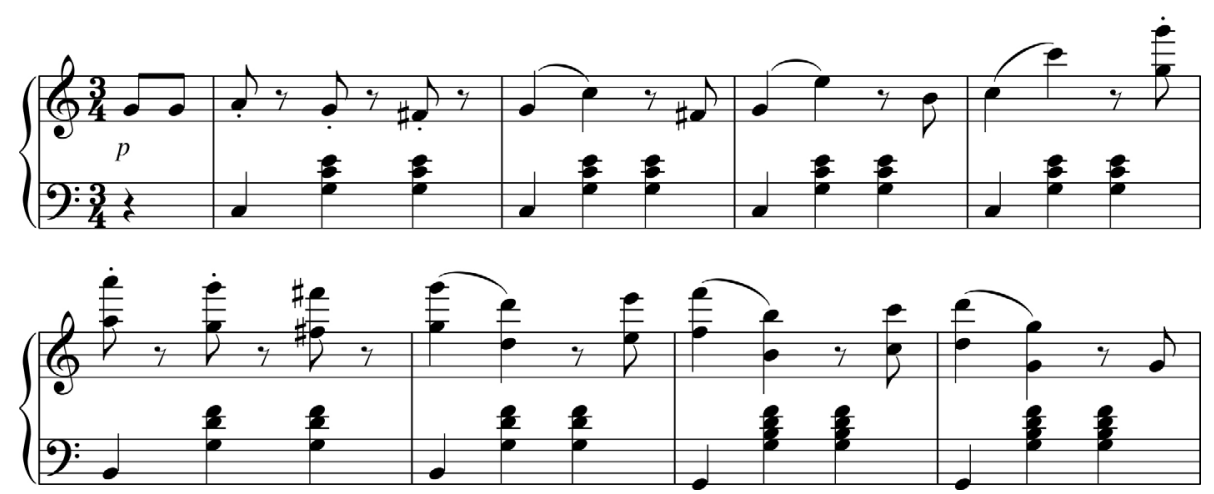

The evocation of the train is also heard in the French horn sounds that are used to represent the sound of the train's whistle in the opening bar of Waltz No. 2:
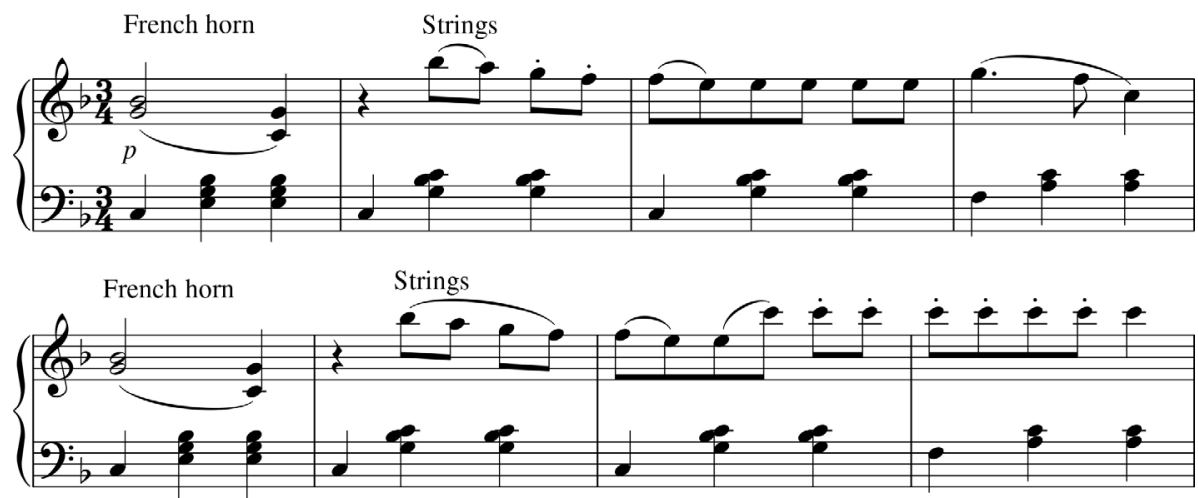
The final section, the Coda, brings back the earlier waltz themes and the journey reaches its end with an emphatic cadence.

By this time Strauss's reputation had spread abroad and at the beginning of 1837 , the Eisenbahn-Lust-Walzer were published, and well received, in England. There were several newspaper reviews including this one from the Brighton Gazette.

\section{THE RAILROAD WALTZES by JOHANN STRAUSS}

These are some of the very prettiest waltzes of this celebrated composer, and, in the present railway mania, are likely to become extremely popular, were it only for their name. They are, however, independently of that circumstance, extremely good.

Brighton Gazette (9 February, 1837)

\section{Accellerationen (Accelerations)}

It is interesting to note that although so many of the Strauss brothers' pieces are related to travel, none of them ever undertook journeys willingly and Johann II was apparently filled with terror at the mere mention of the precipices on the mountain stretches over the Semmering, ${ }^{18}$ Johnson writes that the 'new energy and kinds of motion engendered by new technologies' were often reflected in the titles of the Strauss pieces e.g. Johann Strauss II's 'Spirals' and 'Accelerations. ${ }^{19}$ He argues that dance titles such as Ohne Bremse (Without Brakes), Feuerfunken (Sparks of Fire) and Ohne Aufenthalt (Non Stop), play on the frisson of danger of the express train ride but also blur the distinction between the physical sensations linked to new technologies of transport with those of sexual excitement. ${ }^{20}$ Sigmund Freud was later to express this more directly when he wrote 'A compulsive link of this kind between railway-travel and sexuality is clearly derived from the pleasurable character of the sensations of movement. ${ }^{21}$

This link between sexuality and the motion of a train is clearly portrayed in Accellerationen (Accelerations). ${ }^{22}$ Written in 1860 for the Engineering Students' Ball held on February 14 in the Sofienbad-Saal and completed at the last moment, 'the barely concealed sexual excitement of its accelerating motion can hardly have disappointed the young engineers and their dancing partners. ${ }^{23}$ The journey gets off to a gentle start in the Introduction with tentative huffing and 
puffing in the lower registers, very gradually getting louder and gathering speed. The Introduction ends with two hoots on the train whistle, provided by the woodwind, helping to set the scene. Although Accellerationen starts off quietly, in contrast with the explosive start of the Eisen-Babn-Waltzer, the younger Strauss adopts some of the same compositional techniques as his father such as tremolo strings and rising chromatic scale passages. The excitement builds up again in Waltz No. 1 which starts off quietly with trembling strings building up with furiously driving crescendo as the engine accelerates. Four more waltzes follow, each of them with powerful build-ups and crescendos, not least in the Coda which ends with a loud rising bass line, reinforced by snare drums and kettle drums towards the triumphant loud chords of the final cadence.

Accellerationen was not the only train-inspired piece by Johann Strauss II, he composed at least two more: Spiralen (Spirals, 1858); and Vergnügungszug (Pleasure Train Polka, 1864). For several seasons he took his orchestra to play in residence at the Vauxhall Pavilion ${ }^{24}$, an elegant music pavilion and entertainment venue in Pavlovsk, the end station of the first 19-mile stretch of the Russian Tsarskoe Selo Railway. There they played ten successful (and well paid) summer seasons (1856-65) with further short visits later on. Strauss and his orchestra were one of the attractions, giving concerts every evening between May and September, encouraging well-to-do St. Petersburgers to use the new means of transport to travel there, thus helping to make the railway more profitable. Apparently these popular concerts were brought to an abrupt halt when the guard's whistle sounded for the last train to St Petersburg. ${ }^{25}$

\section{The polkas}

The polka originated in Bohemia in the 1830s and later became very popular as a ballroom dance in Vienna, largely thanks to the Strauss family. A lively dance for couples, it is performed with light hopping steps. Musically it has two beats to a bar and rhythms made up largely of quavers and semi-quavers in two-bar phrases. In Viennese ballrooms two distinct forms evolved, the graceful Polka française and the quicker Schnell-Polka. Eduard, who was often referred to as 'der schöne Edi' (handsome Edi) had a successful musical career winning international acclaim as a conductor. In terms of composition, he was particularly famed for his polkas, carving out a niche writing in the hectic 
schnell polka style. His piece Mit Dampf (With Steam, 1871) is a typical example of the form. It is in ternary form (three sections) - Main polka theme, Trio and Finale. The first section of Mit Dampf has a fast and loud four-bar introduction (accompanied by a train whistle on some recordings) which heralds the main theme. The Trio then introduces a new theme using dotted notes and leaps. This is followed by the last section, the Finale. The Finale recaps the first section complete with its introductory train whistle heard on some recordings, and the rhythmic metallic sound as the train passes over the sleepers, cymbal crashes and plenty of percussion to add to the excitement. The polka dance ends with a final hoot from the train whistle.

\section{Danger on the trains}

Trains promised speed but also danger. These aspects of train travel are emphasised in the titles of two of Eduard Strauss's fast polkas: the raucous Ohne Bremse (Without Brakes) and Obne Aufenthalt (Non Stop) which opens with a clanging bell in many performances and ends with a piercing (piccolo) guard's whistle. Instructions for first-time riders on the Nordbahn included prominent warnings against any attempt to leap from the car, which it suggests, occasionally happened when the steam engine's whistle blew. ${ }^{26}$

Train accidents across Europe and the USA were a common occurrence in the nineteenth century and newspapers were quick to report them.

On the morning of 7 July, 1839, three trains operated by the Kaiser Ferdinands-Nordbahn, arrived at Brno/ Brünn...As one local newspaper correspondent wrote... In little time the first of three trains from Vienna pulled into the station. "With speed like the wind," it had covered the roughly 130 kilometers from the imperial capital to Brno in just four and a half hours. ...That afternoon the three trains departed for Vienna, and within hours horrible news had reached Brno: the third train had slammed into the second train at a small station north of Vienna... a number of people had been injured, several of them seriously. Later investigations showed that the engineer of the third train had exceeded the company's speed limit, resulting in brake failure. ${ }^{27}$

The Nordbahn suffered several tragedies in the year that followed including a fire that broke out in the Vienna train station seriously damaging a number of cars. ${ }^{28}$ 


\section{Pleasure trips}

Danger or no danger, hundreds of Austrians were happy to take the many train trips on offer out of Vienna. The construction of the railways made trips into the countryside and fashionable spa towns not only much cheaper, and therefore no longer the sole preserve of the rich, but also possible to cover in one day. The first travel agent was opened in Vienna in 1866 and was run by Gustav Schrökl and his wife Therese. They organised a variety of train excursions: tours; trips to the theatre; trips to exhibitions; and pleasure trips. The MorgenPost newspaper, reported that on one such pleasure trip from Innsbruck to Vienna in 1874, the passengers were cramped together, the food ran out and they had to endure a 36-hour return trip to Vienna referring to Schrökl's trips as "The pleasure-seekers terror."

Several of the Strauss dance works celebrated pleasure trips including Johann Strauss II's Vergnügungszug (Pleasure Train Polka); and Eduard Strauss's Tour und Retour (Round Trip) and Lustfahrten (Pleasure Journeys). Johan Strauss II composed Vergnügungszug in 1864 for the Association of Industrial Societies Ball held in the ballroom of the Imperial Palace in Vienna. It uses the instruments of the orchestra to conjure up the sounds of the train; the piccolo represents the station master's whistle and syncopated horns signal warnings of the train's approach as it flies through the countryside. Johann Strauss II took the piece to Pavlovsk for his 1864 concert season. It was played at the opening concert and proved to be so popular that it was played many more times during his residency there.

Several other Strauss railway pieces were written for balls. In 1860 Josef Strauss composed the polka Gruß an München (Greetings to Munich), a Polka française for a party to celebrate the inauguration of the Vienna-Salzburg railway line, the Empress Elisabeth Railway, and much of Eduard's railway music was written for balls in Vienna commissioned by railway officials.

\section{Babn frei! Line Clear!}

One such work was Bahn Frei! (Line Clear!, 1869). The piece, a quick polka, was written for the ball of the railway employees of the Nordbahn. Some joked that it was played at a much quicker tempo than the Nordbahn trains could 
actually travel at. ${ }^{30}$ Babn Frei! opens in imitation of a train with stuttering woodwind playing short quiet notes, getting louder and faster building up to piercing shrill high notes from the piccolo and flute - the guard's whistle announces the line is clear. The engine starts with a mechanical chugging rhythm on pizzicato strings, the polka melody begins and the full orchestra joins in as the journey gets underway. It is not difficult to see how the laboured departure of a steam engine, building up to a quicker development and finally a coda as the passengers reach the end of their journey is a handy template for composers to follow.

Johnson writes that some of the Strauss railway pieces were written

in a form that became standard for all future 'train pieces' - beginning with the gathering of momentum from a standing start and ending by a corresponding wind down. In between the mechanical rhythm of the engine becomes the background accompaniment to melodic writing for the strings, suggesting the romanticized glamour of gliding through the landscape, elegantly motionless in one's own body even while the vehicle speeds along. ${ }^{31}$

There is much that is true in this statement, but the Strauss railway pieces do not usually end with a 'wind down'. Bearing in mind that they were written in part to be danced to and that they acted as showpieces for the Strauss Orchestra, it is not surprising that rather than petering out, most end with a huge orchestral splash. The final bars of Bahn frei! are typical - a crescendo building up to fortissimo final chords with trills, crashing cymbals, and rolls on the drums.

\section{End note}

Some readers may wonder why there has been no mention of Johann Strauss II's Reise Abenteuer (Travel Adventures), a piece which is often included in recordings and lists of railway pieces. It would appear that these were not railway adventures, but adventures at sea. The cover of the first piano edition features a vignette of a paddle-steamer being tossed in a violent storm $^{32}$ and is a reflection of Strauss's own experience. In 1857 he had travelled by sea to Russia enduring a terrible storm. The impressive Coda is a dramatic musical depiction of storm-lashed vessels pitching and rolling, while the wind rages and the lightning flashes. 


\section{Endnotes}

1 Hobsbawm, Eric. (Industry and Empire: From 1750 to the Present Day. (London: Penguin, 1969): 110-111.

2 Jeffrey Richards and John M MacKenzie. The Railway Station: A Social History. ( Oxford: Oxford University Press, 1986).

3 České Budějovice in the present day Czech Republic.

4 Chad Bryant. 'Into an Uncertain Future: Railroads and Vormärz Liberalism in Brno, Vienna, and Prague', Austrian History Yearbook, 40 (2009): 187.

5 Christian Wolmar. The Golden Age of European Railways. (Barnsley: Pen \& Sword Transport, 2013): 138-148.

6 Robert Barry. The Music of the Future. (London: Repeater Books, 2016): 89.

7 Peter Kemp. The Strauss Family. Portrait of a Musical Dynasty. (Tunbridge Wells: The Baton Press, 1985):16.

8 Journal des Débats, 10 November, 1837.

9 Orlando Figes. The Europeans: Three Lives and the Making of a Cosmopolitan Culture. (London: Penguin, 2020): 272.

10 Kemp, The Strauss Family, 155-157.

11 Kemp, The Strauss Family, 157.

12 Figes, The Europeans, 121.

13 Barry, The Music of the Future, 89.

14 Gustave Flaubert, Madame Bovary. (Minneapolis, Minnesota: Lerner Publishing Group, 2016): 58

15 Andrew Lamb. 'Waltz' in Grove Music Online.

16 The Russian diplomat Prince Razumovsky had lived at The Golden Pear for a few days, as had the playwright and novelist Honoré de Balzac. Ludwig van Beethoven was a regular customer between 1823-4 when he lived in the same area.

17 Julian Johnson. Out of Time: Music and the Making of Modernity. (Oxford: Oxford University Press, 2015): 102.

18 Kemp, The Strauss Family, 80.

19 Johnson, Out of Time, 102.

20 Johnson, Out of Time, 101.

21 Sigmund Freud. The Complete Psychological Works Of Sigmund Freud, Vol 7: "A Case of Hysteria", "Three Essays on Sexuality" and Other Works. (London: Hogarth Press, 1953): 202.

22 Johnson, Out of Time, 101.

23 Johnson, Out of Time, 102.

24 Named after the Vauxhall Pleasure Gardens in London.

25 Orlando Figes, The Europeans, 274.

26 Bryant. "Into an Uncertain Future": 195.

27 Bryant, "Into an Uncertain Future", 183.

28 . Bryant, "Into an Uncertain Future", 195.

29 Martin Scheutz, "Die Geschichte der Reisebüros" in Fernweh und Stadt. Tourismus als städtisches Phänomen (Innsbruck: Studien Verlag, 2018): 151-152.

30 https://wjso.or.at/de-at/Home/Events/EventDetail?ConcertID=813\&WerkID=468

31 Johnson, Out of Time, 102.

32 Published by Haslinger in 1860 . 
10.5920/railways.5 